\title{
Gerakan Sosial Masyarakat Peduli Lingkungan
}

\author{
Abd. Rahman \\ Syaribulan K \\ Universitas Muhammadiyah Makassar \\ syaribulan@unismuh.ac.id
}

\begin{abstract}
ABSTRAK
Setiap individu atau kelompok memiliki kepedulian terhadap lingkungan hidup, tak terkecuali masyarakat Awangpone, masyarakat sudah sadar dengan kebersihan lingkungan yang sesuai motto Kabupaten Bone yaitu Green and Clean yang artinya hijau dan bersih.Tujuan penelitian ini untuk mengetahuiGerakan Sosial Masyarakat Peduli Lingkungan Di Awangpone Kabupaten Bone. Jenis penelitian ini adalah penelitian sosial budaya (PSB) dengan tipe deskriptif kualitatif, yaitu memberikan gambaran tentang perubahan sosial ekonomi terhadap masyarakat. Pengumpulan data dalam penelitian ini dilakukan dengan cara observasi, wawancara dan dokumentasi. Dalam penelitian ini responden di pilih langsung oleh peneliti yang disebut sasaran penelitian yaitu 10 orang.Hasil penelitian ini menunjukkan bahwa Gerakan sosial peduli lingkungan adalah salah satu cara masyarakat untuk menjaga kelestarian alam serta menyelamatkan ekosistem alam selain itu dengan terjaganya lingkungan masyarakat secara otomatis mempengaruhi kesehatan masyarakat untuk hidup sehat di Kecamatan Awangpone. Dan selain kelebihan tersebut masi juga terdapat kekurangan yang dimana masih ada masyarakat yang bermasa bodoh dan tidak peduli dengan lingkungannya, dan kurangnya kerjasama antara pemerintah desa dengan Kecamatan sehingga program tersebut tidak berjalan sesuai dengan apa yang diinginkan.
\end{abstract}

Kata Kunci : Gerakan Sosial, Masyarakat, Peduli Lingkungan.

\section{PENDAHULUAN}

Ditingkat nasional, lahirnya undang-undang nomor 4 tahun 1982 tentang ketentuan-ketentuan pokok pengelolaan lingkungan hidup, tanggal 11 maret 1982 dipandang sebagai pangkal tolak atau awal dari lahir dan pertumbuhan hukum lingkungan nasional modern. Pada periode 1960-an, perkembangan teori gerakan sosial memasuki era baru dalam dunia akademis terutama di Negara-negara Amerika Utara dan Eropa Barat sebelum era yang ditandai dengan ditransformasikannya teori gerakan sosial kelasik menjadi lebih modern dengan mempergunakan teori-teori yang telah dikembangkan oleh akademisi teori gerakan sosial sebelumnya atau thesis baru dari kritik terhadap teori yang telah tersedia.Teori gerakan sosial modern berhasil mengidentifikasi faktor-faktor apa saja yang memfasilitasi tumbuhnya gerakan sosial, kuat lemahnya dan berhasil atau tidaknya sebuah geraka sosial. 
Lingkungan hidup menjadi masalah yang sangat populer di dunia.Temanya apalagi kalau bukan Pemanasan Global akibat perubahan iklim yang sangat ekstrim di dunia.Masalah pemanasan global atau global warming ini menjadi suatu masalah yang selalu diperbincangkan oleh banyak orang dan penulis melihat ada semacam euforia global warming di dunia. Selama 20 tahun belakangan ini, isu tentang lingkungan menjadi sesuatu yang paling sering diperbincankan. Semakin parahnya isu lingkungan, semakin banyak muncul gerakan perlindungan lingkungan, dan konferensi - konferensi yang digelar terkait dengan isu - isu pemanasan global. Konferensi yang diadakan tidak hanya konferensi yang diadakan oleh PBB sebagai organisasi terbesar dunia, tapi juga konferensi yang digelar oleh gerakan grassroots dan kelompok kepentingan yang memiliki perhatian pada masalah lingkungan.

Contohnya di Indonesia, beberapa tahun belakangan ini, pergantian musim di Indonesia tidak jelas lagi, dan dibeberapa daerah yang dulunya berhawa dingin, tidak lagi terasa seperti itu. Sehingga pemerintah daerah bekerjasama dengan beberapa lembaga dan masyarakat dalam melakukan gerakan sosial peduli lingkungan di Kecamatan Awangpone Kabupaten Bone.

Pemerintah Indonesia sudah punya gerakan untuk mengerem laju pemanasan global melalui gerakan satu orang satu pohon (one man one tree), dengan gerakan ini diterapkan oleh masyarakat setempat yang sangat membantu ekosistem dan pelestarian lingkunan di Kecamatan Awangpone Kabupaten Bone, yang dimana lingkungan disekitar pinggir pantai bisa dilestarikan kembali dengan adanya kegiatan gerakan sosial ini.Dengan melihat bahwa lingkungan disekitar pinggir pantai ini sangat memperihatinkan dan butuh perlindungan dari penduduk, dan pemerintah setempat untuk mempebaiki kembali ekosistem disekitar pantai.

\section{LANDASAN TEORI}

Wood dan Jackson (dalam Sztompka, 1994) menyatakan bahwa perubahan social merupakan basis yang menentukan ciri-ciri gerakan sosial, dan gerakan sosial berkaitan erat dengan perubahan sosial. Ada banyak defenisi mengenai gerakan social, gerakan social sering diidentikkan dengan masalah politik, karena memang gerakan social lahir dari sebuah kepentingan individu atau kelompok masyarakat, baik yang terorganisasi maupun tidak.Gerakan social pada hakikatnya merupakan hasil perilaku kolektif, yaitu sebuah perilaku yang dilakukan bersama-sama oleh sejumlah orang tidak bersifat rutin dan perilaku mereka merupakan hasil tanggapan atau respons terhadap ransangan 
tertentu.Akan tetapi, gerakan social berbeda dengan perilaku kolektif.Gerakan social sifatnya lebih terorganisasi dan lebih memiliki tujuan dan kepentingan bersama dibandingkan perilaku kolektif. Perilaku kolektif dapat terjadi secara spontan, namun gerakan social memerlukan sebuah penggorganisasian massa. Sunarto dalam Nanang Martono (2011:223).Sztompka dalam Nanang Martono (2011:225), memberikan batasan definisi gerakan sosial. Menurutnya, gerakan social harus memiliki empat kriteria, yaitu: pertama, adanya kolektivitas; kedua, memiliki tujuan yang bersama, yaitu mewujudkan perubahan tertentu dalam masyarakat mereka yang ditetapkan partisipasi menurut cara yang sama.ketiga, kolektivitasnya relative tersebar namun lebih rendah derajatnya dari pada organisasi formal. Keempat, tindakannya memiliki derajat spontanitas tinggi namun tidak terlembaga dan bentuknya tidak konvensional

Ada beberapa bentuk atau klasifikasi gerakan sosial. Klasifikasi tersebut didasarkan pada beberapa kriteria, yaitu: pertama, menurut bidang perubahan yang diinginkan, kedua, menurut kualitas perubahan yang diinginkan. Ketiga, menurut target perubahannya.Keempat, menurut arah perubahan yang diinginkan.Kelima, menurut strategi yang mendasari atau" logika tindkan mereka".Keenam, menurut sejarah perkembangannya Sztompka dalam Nanang martono (2011:230).Dampak negatif dari menurunya kualitas lingkungan hidup baik karena terjadinya pencemaran atau terkurasnya sumber daya alam adalah timbulnya ancaman atau dampak negatif terhadap kesehatan, menurunnya nilai estetika kerugian ekonomi (economi cozt), dan terganggunya sistem alami (Natural system).Menurut Rahmadi (2014:1-3).

Pencegahan pengrusakan laut dilakukan dengan langka-langka berikut melarang perbuatan yang dapat menimbulkan kerusakan laut, mewajibkan keiatan usaha melakukan pencegahan, penanggulangan. Penanggulangan pencemaran dan perusakan laut dilakukan dengan langka-langka berikut: mewajibkan kegiatan usaha melakukan pemulihan mutu laut, mejibkan kegiatan usaha menanggung biaya penanggulangan dan pembayaran ganti kerugian. Pengendalian pencemaran laut dilakukan melalui penggunaan instrumentinstrumen berikut: baku mutu air laut, criteria baku kerusakan air laut, izin melakukan damping dan pengawasan. Dalam Rahmadi (2014:150-151).Limbah dari darat juga dapat mengendap diekosistem mangrove namun jika limba tersebut berupa bahan kimia berbahaya makan akan diserap biota akuatik terutama kerang sehingga terakumulasi didalam tubuhnya, dan akhirnya biota tersebut berbahaya untuk dikonsumsi. Dalam Ghufran (2012:70-71). 
Pada semua masyarakat modern, selalu saja terdapat kadar ketidakpuasan memang merupakan kondisi ketidakpuasan itu sendiri belum cukup untuk membangkitkan munculnya gerakan sosial. Dalam Nanang Martono (2011: 228-229) .Oleh karena itu menurut libertarianisme hukum lingkungan harus mewajibkan para pelaku untuk terus menerus meminimalisasi tingkat pencemaran atau perusakan lingkungan dan kemudian meniadakan sama sekali pencemaran dan perusakan lingkungan. Hal ini dapat di lakukan dengan merumuskan peraturan perundanganundangan yang dapat mendorong lahirnya inovasi teknologi pencegah pencemaran ( technology-forcing pollution control legislation). Menurut Rahmadi (2014:35-36).

Metode Penelitian.

\section{METODE PENELITIAN}

Jenis penelitian yang yaitu deskriptif kualitatif yang bertujuan memahami bentukbentuk gerakan sosial peduli lingkungan dan kendala-kendala gerakan sosial peduli lingkungan di Kecamatan Awangpone Kabupaten Bone. Informan ditentukan secara purpose sampling, teknik pengumpulan data yakni observasi, wawancara, dan dokumentasi, kemudian dianalisis melalui tahapan pengumpulan data (data collection), reduksi data (data reduction), penyajian data (display data), penarikan kesimpulan (conclusion) dan menggunakan teknik keabsahan dan triangulasi sumber, teknik, dan waktu.

\section{PEMBAHASAN}

Pelestarian lingkungan hidup pada hakikatnya merupakan tanggung jawab semua pihak,tidak terkecuali masyarakat.oleh karena itu ,pemerintah harus berupaya memotivasi masyarakat agar ikut berpartisipasi secara aktif dalam lingkungan hidup,baik di sekitar tempat tinggalnya maupun lingkungan kelurahannya. Hal ini sangat penting karena pengelolaan lingkungan hidup sangat terkait dengan aspek kesehatam masyarakat.Gerakan sosial peduli lingkungan Kecamatan Awangpone cukup berhasil karena masyarakatnya sudah sadar betapa pentingnya kesehatan, kebersihan lingkungan yang sesuai dengan Motto Kabupaten Bone yaitu Green And Clean.

Adapun landasan teori yaitu teori motivasi Maslow dalam Rekhadi Projo dan Handoko (1996) membagi kebutuhan manusia sebagai berikut (1) Kebutuhan Psiologis merupakan hirarki kebutuhan manusia yang paling dasar yang merupakan kebutuhan untuk dapat hidup seperti makan, minum, perumahan, oksigen, tidur dan sebagainya. (2) 
Kebutuhan rasa aman apabila kebutuhan psiologis relatif sudah terpuaskan maka muncul kebutuan yang kedua yaitu kebutuhan rasa akan aman. Kebutuhan rasa akan aman ini meliputi keamanan dan perlindungan dari bahaya kecelakaan kerja, jaminan akan kelangsungan pekerjaannya dan jaminan akan hari tuanya. (3) Kebutuhan Sosial yaitu kebutuhan akan persahabatan, apiliasi dana interaksi yang lebih erat dengan orang lain. Dalam organisasi akan berkaitan denagan kebutuhan dengan adanya kelompok kerja dengan kompak, supervisi yang baik, rekreasi bersama dan sebagainya. (4) Kebutuhan penghargaan, kebutuhan ini meliputi kebutuhan ke inginan untuk dihormati, dihargai, atas perestasi seseorang, pengakuan atas kemampuan dan keahlian seseorang serta efektifitas kerja seseorang (5) Berkaitan dengan proses pengembangan potensi yang sesungguhnya dari seseorang.

Teori Maslow mengasumsikan bahwa orang berkuasamemenuhi kebutuhan lebih pokok sebelum mengarahkan perilaku memenuhi kebutuhan yang lebih tinggi.Upaya pemerintah dalam meningkatkan partisipasi masyarakat dalam pengelolaan lingkungan hidup,yaitu bahwa dalam rangka mewujudkan visi pembangunan kesehatan kota bone, maka pemerintah Kecamatan Awangpone membentuk forum komunikasi Kecamatan sehat Kecamatan Awangpone dengan tujuan yaitu ; 1) merancang program pengembangan kabupaten sehat tingkat Kecamatan berdasarkan tatanan yang di pilih untuk dikembangkan, 2) Melakasanan sosialisasi dan advokasi pengembangan kabupaten sehat, 3) memberikan penyuluhan dan pengarahan agar tidak membuang sampah di sembarang tempat,memberikan pengarahan tentang pentingnya lingkungan hidup sehat,bersih dan lestari. Pemberian pengarahan kepada masyarakat tentang pentingnya hidup sehat,bersih dan lestari tidak hanya dilakukan aparat pemerintah kelurahan tetapi juga dilakukan oleh pihak posyandu dan ibu PKK. Pemberian pengarahan tersebut terutama dilakukan saat masyarakat melakukan kegiatan bersama tim penggerak PKK, maupun mengikuti kegiatan posyandu. Adanya pengarahan tentang pentingnya hidup sehat, bersih dan lestari tersebut sangat penting, mengingat hal tersebut sangat berkaitan dengan upaya peningkatan derajat kesehatan masyarakat.Karena faktor kesehatan sangat terkait dengan masalah kebersihan, sehingga, kegiatan penyuluhan merupakan hal yang paling penting dilakukan pemerintah kelurahan dengan segala perangkatnya.

Pemerintah Kecamatan senantiasa berupaya secara berkala untuk melakukan berbagai agar masyarakat dapat ikut berpartisipasi dalam pengelolaan lingkungan hidup. Baik sekitar lingkungan tempat tinggalnya maupun lingkungan kelurahannya.Hal ini 
sangat penting karena pengelolaan lingkungan hidup sangat terkait dengan aspek kesehatan masyarakat. Menurut asumsi penulis partisipasi masyarakat dalam pengelolaan atau penataan lingkungan pekarangan sangat penting mengingat kesuksesan dalam kegiatan pengelolaan lingkungan sangat bergantung dari kesadaran dan partisipasi masyarakat dan pemerintah harus jadi motivator dan fasilitator yang memungkinkan penataan lingkungan pekarangan dapat berlangsung dengan baik.Berbagai keuntungan yang dapat diperoleh oleh masyarakat sebagai dampak dari penataan lingkungan pekarangan.Keuntungan atau manfaat yang diperoleh sangat terkait dengan jenis pemanfaatan lingkungan tanah pekarangannya.Masyarakat Kecamatan Awangpone maka dapat di peroleh informasi tentang keuntungan-keuntungan yang mereka peroleh dengan pemanfaatan atau penataan lingkungan pekarangan, yaitu dapat meningkatkan derajat kesehatan masyarakat. Dengan pemanfaatan atau penataan lingkungan pekarangan dengan baik, akan memungkinkan kebersihan lingkungan dapat terjaga dengan baik. Kondisi tersebut akan memberi dampak positif terhadap peningkatan derajat kesehatan. Karena faktor kesehatan sangat terkait dengan faktor kebersihan lingkungan tempat tinggal.Hal tersebut sangat relevan dengan pernyataan responden yang senantiasa melakukan pembersihan lingkungan sekitar tempat tinggalnya yang memungkinkan mereka dapat hidup bersih.Menciptakan kenyaman hidup dalam kehidupan sehari-hari. Dengan tertatanya lingkungan pekarangan dengan baik akan memungkinkan anggota keluarga dapat hidup dengan nyaman dengan udara yang segar dan bersih. Dengan kata lain, kenyamanan dalam kehidupan sehari-hari tidak terlepas dari kondisi tempat tinggal yang aman dan bersih melalui penataan tempat tinggal secara baik.

Dapat diperoleh seperti apotik hidup dan sayur-sayuran. Pemanfaatan lingkungan pekarangan dengan menanam apotik hidup dan sayur - sayuran akan memberi manfaat yang sangat besar dalam keluarga, seperti akan sangat bermanfaat jika ada warga masyarakat yang sakit untuk dimanfaatkan sebagai pertolongan pertama dan sumber gizi.Adanya berbagai keuntungan dari penataan lingkungan di pekarangan di Kecamatan Awangpone, tentu akan menjadi pelajaran bagi warga masyarakat lainnya untuk dapat berusaha memanfaatkan lingkungan pekarangannya secara baik dengan menanami berbagai macam tanaman yang bermanfaat. Karena kenyataanya melalui penataan lingkungan dengan pemanfaatan pekarangan secara optimal akan dapat memberi dampak terhadap kesehatan masyarakat, kenyamanan sekaligus dapat memperoleh hasil atau manfaat berupa hasil tanaman pekarangan. Penataan lingkungan pekarangan tidak terlepas dari perlunya keterlibatan masyarakat secara aktif. Keterlibatan masyarakat 
dalam pengelolaan lingkungan hidup dalam bentuk partisipasi tidak hanya terbatas pada menjaga kelestarian lingkungan, tetapi juga diikuti dengan upaya terlibat secara aktif dalam pelestarian lingkunngan, seperti penanaman penanaman tanaman disekitar rumah dan melakukan pembersihan lingkungan tempat tinggalnya. Karena jika lingkungan hidup kurang mendapat perhatian, maka tidak mustahil akan memberi dampak aktor terhadap kehidupan manusia seperti munculnya berbagai macam penyakit akibat dari kerusakan lingkungan hidup.

Pelestarian lingkungan hidup tidak hanya menjadi tanggung jawab pemerintah tetapi juga masyarakat.Oleh karena itu, sudah seharusnya setiap anggota masyarakat menyadari dan ikut secara aktif dalam pengelolaan lingkungan hidup. Terutama pada lingkunngan tempat tinggalnya, dimana hal tersebut diatur dengan tegas dalam UndangUndang Nomor 23 tahun 1997 tentang pengelolaan lingkungan hidup yang memberikan pengetahuan dan kesadaran bagi masyarakat akan pentingnya pelestarian lingkungan hidup. Karena partisipasi aktif dari masyarakat, mustahil lingkungan hidup dapat dijaga kelestariannya.Sehubungan dengan itu pulalah, maka sudah seharusnya pemerintah melakukan sosialisasi atau penyuluhan tentang pentingnya partisipasi masyarakat dalam pengelolaan lingkungan hidup dan berbagai upaya-upaya lainnya, baik secara preventif maupun represif.Dari pengelolaan lingkungan hidup tersebut, khususnya lingkungan tempat tinggal masyarakat tentunya diharapkan berbagai keuntunngan yang dapat diperoleh masyarakat.

Tingkat partisipasi masyarakat dalam kegiatan penataan lingkungan pekarangan, termasuk dalam kategori tinggi, walaupun sebagian ada yang termasuk dalam kategori cukup tinggi namun tidak ada dalam kategori rendah dan sangat rendah partisipasinya. Hal ini berarti masyarakat sangat menyadari pentingnya menjaga lingkungan hidup sehingga tergerak untuk berpartisipasi dengan menjaga dan melestarikan lingkungan hidup disekitar tempat tinggalnya.Adanya partisipasi masyarakat dalam penataan lingkungan pekarangan merupakan cerminan dari kesadaran masyarakat tentang pentingnya lingkungan hidup demi kehidupannya, dan pemerintah seharusnya merespon hal tersebut dengan berupaya melakukan berbagai upaya agar masyarakat lebih meningkatkan partisipasinya dalam pengelolaan lingkungan hidup di Kecamatannya.

Berbagai upaya telah ditempuh dalam peningkatan partisipasi masyarakat di Kecamatan awangpone dalam kegiatan penataan lingkungan pekarangan. Upaya-upaya tersebut berupa memberikan penyuluhan dan pengarahan agar tidak membuang sampah di sembarang tempat terutama di sekitar tempat tinggalnya, dan memberikan pengarahan 
tentang pentingnya hidup sehat, bersih dan lestari dengan menjaga lingkungan tempat tinggalnya dengan melakukan pembersihan setiap saat dan tidak membuang sampah di sembarang tempat. Adanya lingkungan hidup yang bersih pada hakikatnya akan memberi dampak juga bagi masyarakat. Oleh karena itu, sudah seharusnya masyarakat menyadari betapa pentingnya berpartisipasi dalam melestarikan lingkungan hidup, terutama lingkungan tempat tinggalnya maupun lingkungannya. Dari hasil penelitian menunjukkan bahwa berbagai keuntungan yang dapat di peroleh masyarakat, dalam penataan lingkungan, khususnya penataan lingkungan pekarangan rumah penduduk, berupa : dapat meningkatkan derajat kesehatan masyarakat karena adanya upaya menjaga kebersihan lingkungan tempat tinggalnya ; menciptakan kenyaman hidup dalam kehidupan seharihari, dan dapat di peroleh seperti apotik hidup melalui pemanfaatan lingkungan pekarangan untuk berbagai jenis tanaman yang bermanfaat. Dengan kata lain, tanah pekarangan tempat tinggal tidak dibiarkan kosong atau ditumbuhi tanaman yang tidak bermanfaat, tetapi dengan pemanfaatan berbagai tanaman seperti apotik hidup tentu akan memberi manfaat yang lebih besar bagi kehidupan masyarakat sehari - hari, sehingga memberi konsekuensi pada perlunya kesadaran masyarakat untuk memanfaatkan lingkungan pekarangannya atau di sekitar tempat tinggalnya.

Adanya keuntungan yang di peroleh masyarakat melalui pengelolaan lingkungan hidup khususnya dalam penataan lingkungan tentu memberikan kesadaran bagi masyarakat Kecamatan Awangpone untuk lebih memanfaatkan lingkungan tempat tinggalnya dengan baik yang memungkinkan banyaknya manfaat yang diperoleh, seperti dengan adanya penataan lingkungan pekarangan akan memungkinkan masyarakat dapat meningkatkan derajat kesehatannya karena faktor kesehatan sangat ditentukan oleh faktor lingkungan tempat tinggal. Demikian pula dapat memberi manfaat ekonomi karena dengan pemanfaatan lingkungan pekarangan dari apotik hidup maupun sayur-sayuran yang dapat dimanfaatkan setiap saat.

\section{KESIMPULAN}

1. Gerakan Sosial peduli lingkungan masyarakat Awangpone yang dimulai pada tahun 2011 tidak berstruktur dan bersifat spontan, tetapi berubah lebih ke arah maju dengan membuka jalur hukum dan membentuk sebuah organisasi. penulis menyimpulkan bahwa masyarakat telah menyadari pentingnya lingkungan yang sehat terutama di lingkungan masyarakat. 
2. Adapun bentuk-bentuk gerakan sosial peduli lingkungan yang ada di Kecamatan Awangpone yaitu: jamban sehat, memanfaatkan lingkungan pekarangan rumah dan menjaga kebersihannya, dan menanam pohon.

3. Upaya masyarakat Awangpone menjaga solidaritas gerakannya, sudah berlangsung selama 3 (tiga) tahun, solidaritas antar warga yang sudah dimulai tahun 2011 sampai saat ini masih di jaga oleh warga, mulai dari pertemuan yang intensif, acara, diskusi, makan bersama, dan nonton bareng ; komunikasi yang baik juga menunjang solidaritas warga yang ada disana baik antar warga maupun dengan pemerintah, bahkan warga juga menggunakan Mesjid untuk menyampaikan informasi yang menjadi salah satu komunikasi yang efektif bagi warga yang ada di Kecamatan Awangpone. Dalam menjalankan gerakan sosial peduli lingkungan ini masyarakat pasti mengalami kendala.

4. Adapun kendala tersebut yaitu: masyarakat bermasa bodoh terhadap lingkungan, lambatnya pemberian data dari kantor desa ke kantor Kecamatan, dan kurangnya kerjasama antara masyarakat dengan pemerintah.

\section{DAFTAR PUSTAKA}

Beilharz, Peter. (2005). Teori-Teori Sosial.Yogyakarta : Pustaka Pelajar.

Herimanto dan Winarno.(2014). Ilmu Sosial \& Budaya Dasar. Jakarta : Bumi Aksara.

Kordi M. Ghufran. (2012). Ekosistem Magrove. Jakarta: Rineka Cipta.

Martono Nanang. (2011). Sosiologi Perubahan Sosial.Jakarta : Rajawali Pers.

Moleong, J.Lexy. (2007). Metode Penelitian Kualitatif.Bandung : Rosdakarya.

Narwoko, Dwi. J dan Suyanto, Bagong. (2010). Sosiologi Teks Pengantar Dan Terapan.Jakarta : Kencana.

Narwoko, Dwi. J dan Suyanto, Bagong. (2011). Sosiologi Teks Pengantar Dan Terapan.Jakarta : Kencana.

Notoatmodjo, Soekidjo. (2003). Prinsip - Prinsip Dasar Ilmu Kesehatan. : Rineka cipta.

Paizaluddin, Ermalinda. (2013). Penelitian Tindakan Kelas Panduan Teoritis dan Praktis.Bandung: Alfabeta.

Rahmadi Takdir. (2014). Hukum Lingkungan. Jakarta: Rajawali pers.

Ritzer, George dan Goodman, Douglas j. (2014). Teori Sosiologi.Bantul. Kreasi Wacana. 
Setia Graha. (2012). Defenisi Gerakan Sosial. (Online) http: // Sosial Sosiologi. Blogspot.com/2012/12/defenisi masyarakat.html.Diakses 03072015.

Soemirat Juli. (2014). Kesehatan lingkungan. Bandung: Gadja Mada University Perss.

Soerjono Soekanto. (2012). Sosiologi Suatu Pengantar.Jakarta : PT. Raja Grafindo Persada.

Sugiyono.(2012). Metode Penelitian Kombinasi (Mixed Methods).Bandung : Alfabeta.

Wahib situmorang abdul.(2013). Gerakan Sosial (teori \& praktik).Yokyakarta : pustaka pelajar.

Waters.(1994). Teori Sosiologi Moderen.Surabaya : Yayasan Kesatuan Umat.

Zulfaidah Idriana.(2013). Pengertian Unsur-Dan-Kriteria-Masyarakat. (online) http://zulfaidaindriana. Blogspot.com/2013/05/pengertian unsur dan kriteria masyarakat.html.Diakses 05 Mei 2013. 